\title{
The Initial Return Performance of UK Property Company IPOs
}

\author{
Winston Sahi and Stephen L. Lee \\ Department of Land Management and Development \\ The University of Reading, \\ Whiteknights, \\ Reading, \\ England \\ RG6 6AW \\ Tel: + $44(0) 1189316338$ \\ Fax: + $44(0) 1189318172$
}

The Initial Return Performance of UK Property Company IPOs

Keywords Property Company IPOs,

\begin{abstract}
This paper presents empirical evidence for a sample of 48 UK property company initial public offerings over the period 1986 to 1995. From which a number of conclusions can be drawn. First, property companies in general show positive average first day returns. Second, the average first day return by property trading companies is significantly higher than that for property investment companies
\end{abstract}




\section{Introduction}

Shares of companies going public for the first time are typically at a price below that achieved on their first day of trading, giving subscribing investors large positive returns (for international evidence of this phenomenon see Ibbotson and Ritter, 1995; Loughran, Ritter and Rydqvist, 1994). Therefore, either the offering price is set too low or the investors systematically overvalue IPOs on the first trading day. Since the results of studies indicate few if any departures from efficiency in the aftermarket (Ibbotson, 1975) positive initial returns can be attributed to a downward bias in the offering price, that is, IPOs are underpriced. No complete explanation of the underpricing phenomenon exists, though various theories based on different rationales shed light on the factors that may be influential. First information asymmetry (Baron, 1982; Rock, 1986), second signalling (Allen and Faulhaber, 1989; Grinblatt and Hwang, 1989; Welch, 1989; Benveniste and Spindt, 1989), third legal liability and litigation risk (Tinic, 1988; Hughes and Thakor, 1992) and finally information cascade effects (Welch, 1992).

In Baron's information asymmetry theory, it is argued that underwriters are better informed about the appropriate price for IPO shares than the issuers, because they possess greater information about investor demand for the securities. In addition underwriters have an incentive to recommend an offering price below the true market value to reduce the marketing effort and to avoid unsold shares. Thus the theory predicts larger average underpricing for IPOs that are subject to greater uncertainty about their market-clearing prices. In contrast, Rock suggests that the information asymmetry is between informed investors and uninformed investors. In particular where rationing occurs, informed investors crowd out uninformed investors leaving uninformed investors receiving allocations that are biased towards less profitable issues. Therefore in order to compensate the uninformed investors for their adverse selection and to induce them to participate in future initial offerings, the company underprice the issue. A cross-sectional implication of Rock's theory which is developed in Beatty and Ritter (1986) is that the greater the uncertainty about the value of the firm on the part of the investor, the greater the underpricing needed to attract uninformed investors. The signalling theories in comparison propose that companies signal their quality by underpricing, intending to make up for the loss by selling subsequent issues on more favourable terms. Litigation risk theories argue underpricing serves as a form of insurance against legal liability and the associated damages to the reputation of investment bankers. In contrast Welch argues that the pricing decisions of issuers reflect information cascades, where later investors rely completely on the purchasing conditions of earlier investors and ignore their own information. Finally, Ruud (1993) argues that whereas all the above assume deliberate underpricing what is actually happening is that the underwriters often buy the IPO shares to prevent their prices falling below the offer price in the first few days post issue. Thus the positively skewed distribution of initial returns is the result of a suppressed left tail.

The majority of such studies are based on industrial companies with established operating assets. Contrary to such findings of positive average initial returns, empirical evidence on certain non-operating asset holding businesses have shown insignificant or negative initial returns. For example, the initial performance of closed-end funds show negative or insignificant initial returns (Weiss, 1989 and Peavy, 1990, in the US; Levis 
and Thomas, 1995, in the UK). Similarly Real Estate Investment Trusts (REITs), the closest equivalent to UK property companies, show insignificant or negative returns (Wang, Chan and Gau, 1992; Below, Zaman and McIntosh, 1995).

In the UK there is no difference in the Stock Exchange's treatment of IPOs of property companies from that of any other companies, apart from the requirement that property companies must also include a valuation certificate of their property portfolio. However UK property companies are made up of property investment companies (PICs), which hold similar commercial property portfolio to REITs, and property trading companies (PTCs) which are more like industrial companies (Barkham, 1997). As a consequence there is greater value uncertainty for the latter than the former, for whereas the rent received by PICs is seen by the market as quality income, trading profits of property trading are regarded as volatile and harder to determine. This difference in their perception is evidenced by the use of different share valuation bases: net asset value (NAV) for PICs and Price Earnings Ratios (PER) for PTCs. This implies that PICs are likely to have similar initial returns to that of REITs and closedend funds and that PTCs are likely to perform more in line with previous studies of industrial companies and show significant underpricing. The different natures of property companies, their differing share valuations and the complexity of their accounts make the assessing of the true market value of a property company's shares difficult and uncertain. However of the two types, the estimation of the 'true' price of PTCs is likely to be more difficult than that of PICs. As a consequence PTCs are more likely to be underpriced than PICs.

Even so the only study of UK property company IPOs, in marked contrast to REIT IPOs, have shown significantly positive average initial returns (Gerlich, Levis and Venmore-Rowland, 1995). The authors of the study conclude that given the similarity of the assets that REITs and property companies hold, the underlying assets are not the cause of the REIT overpricing. Clearly the strength of Gerlich, Levis and VenmoreRowland (1995) argument lies in the assumption of the similarity between REITs and UK property companies. Given the two distinct types of UK property companies, this study argues that the more accurate comparisons are between REITs and PICs IPOs, and between industrial companies and PTCs. Consequently this study extends previous work on REITS in the US and property companies in the UK, by examining whether there is a significant difference in the first day returns of PICs and PTCs.

\section{Non-industrial IPOs}

The majority of studies on IPOs are based on industrial companies with established operating assets. In particular Ibbotson et al (1988) explicitly excluded closed-end funds and REITs from their sample of 8668 IPOs for the period 1960-87, and find an initial average return of 16.37 per cent. Contrary to such findings of positive average initial returns, empirical evidence on certain non-operating asset holding businesses have shown insignificant or negative initial returns that set these latter businesses as a case apart.

For example, closed-end funds, called investment trusts in the UK, are companies that manage a portfolio of shares or other securities with their prices determined in the Stock Exchange. In addition investment trusts can raise long term debt capital and 
become highly geared. Thus their share price is relatively volatile and can deviate substantially from the value of the underlying assets. In studies of IPOs by such companies insignificant initial returns rather than significantly positive returns are the norm. For example, in the US, Weiss (1989) in a study of 64 closed end funds IPOs over the period 1985-7 and Peavy (1990) in a study of 41 closed end funds over the period 1986-7 both reported insignificant initial returns. While in the UK, Levis and Thomas (1995) in a comprehensive study of 105 investment trusts over the period 1984-92 reported an average initial return of 1.91 per cent. However, initial returns varied considerably across the different types of trust in their sample. For example, Far Eastern trusts reported positive initial returns whereas UK ordinary, European and International trusts all reported insignificant initial returns.

Closed end funds are not the only type of IPO associated with insignificant or negative initial returns. Michaely and Shaw (1994) reported that Master Limited Partnerships (MLPs) which invests in oil, gas and real estate have significantly lower initial returns than other IPOs for a study carried out over the period 1984-88. Similarly Real Estate Investment Trusts (REITs) the nearest equivalent to UK property companies (Canon and Vogt, 1995), have shown negative average initial returns. Specifically, Wang, Chan and Gau (1992) in a study of 87 REITs IPOs over the period 1971-88 reported a significant negative average initial return of -2.82 per cent. Below, Zaman and McIntosh (1995) in a study of 58 REITs over the period 1972-89 similarly reported minor negative average initial returns. Peavy (1990) and Ibbotson, Sindelar and Ritter (1988) argue that the insignificant initial returns on closed end funds is supportive of the information asymmetry hypothesis because there is little uncertainty about the underlying value of the funds' assets. Below, Zaman and McIntosh (1995) try to apply the same argument to REITs by unrealistically assuming that the funds raised in the issue, less the costs, are invested in property at the fair market price. Wang, Chan and Gau (1992) argue that Peavy and Ibbotson et al's argument cannot explain the initial returns on REIT IPOs. Because, in contrast to closed-end funds, REITs invest in infrequently traded real estate assets and there is considerable uncertainty about such values, especially when compared to a closed-end investing in shares with observable market values. In particular occasionally, REITs do not specify the assets they will be acquiring with the IPO funds. Thus investors are unable to value the as-yet unidentified real estate assets. Even in cases where the REIT's prospective investments are fully, or partially specified, at the time of the IPO the underlying assets have an uncertain market value. Given this valuation uncertainty, there is little reason to believe that REIT's IPO pricing behaviour should be completely similar to that of closed-end funds.

Nonetheless given that REITs hold a commercial property portfolio, studying UK property IPOs would reveal whether the insignificant average initial return was due to institutional reasons or caused by the underlying assets. Gerlich, Levis and VenmoreRowland (1995) in a study of 51 property company IPOs over the 1981-94 period reported an average initial return of 11.11 per cent. This was lower than Levis's (1993) 14.1 per cent for all IPOs in the UK, but substantially higher than REIT IPOs. Thus concluding that the underlying assets were not the cause of REIT overpricing, supportive of Wang, et al's (1992) criticism of Peavy's and Ibbotson et al's argument. As such no existing IPO theory can explain the significant negative average initial return on REITs. 


\section{UK Property Companies}

Property companies seek to maximise their shareholder value through their interest in property by either trading (or dealing) in land and buildings; or by acquiring standing investments and holding them for their long-term income and capital growth potential, see Barkham (1997). In the process of this they may develop, refurbish or redevelop properties. As such, these property companies can be categorised as either property trading companies PTCs or property investment companies PICs, even though often a company will be involved in both investment and trading. Also, a company's main activity can change as it grows: PTCs often, in time, become PICs as they begin to retain their completed developments as investments. The distinction is important as it may determine the method of their share valuation and their performance when first issuing shares.

PICs usually have substantial portfolios of commercial property investments along with varying amounts of commercial developments in progress. These companies have high levels of asset backing. As such they are valued by the market, less on their earnings and dividends, than according to their underlying estimated current fully diluted net asset value or NAV. If quoted, their share prices are determined by supply and demand on the stock market. In addition property companies normally trade at a discount to their NAV, where a discount to NAV is defined as the companies NAV less its market capitalisation expressed as a percentage of NAV, Adams and VenmoreRowland (1989). A positive value for the discount reflects a market capitalisation that is below the NAV, that is when the share price is below the NAV per share. The discount or premium to NAV varies widely from one company to another and the average discount or premium for the property sector also varies over time. A number of factors have been suggested to explain the discount to NAV including: uncertainty as to true market NAV, the unrealised capital gains liability on disposal of the company's assets and the increased risk in holding property indirectly as a result of high gearing, Adams and Venmore-Rowland (1989).

The first factor, that of uncertainty as to true market value, is of particular importance when sponsors are trying to estimate a new company's share price. There are three particular aspects of property company accounting that cast doubt on the reliability of the NAV figure as stated in the prospectus. First as an exception to the general rule of fixed assets being held in the accounts at historic cost less accumulated depreciation, investment properties - under the Statement of Standard Accounting Practice 19 (SSAP 19) properties are held at their open market value. Due to the investment characteristics of property, specifically the infrequency of transactions, the heterogeneity, and the non-existence of a central market place, resort has to be made to the use of valuation in determining the market price. Various studies have been undertaken to determine whether property valuations are proxies for market prices. Matysiak and Wang's (1995) study of 317 sale/valuations over the 1973-91 period, reported that the probability of the selling price being within plus or minus 10 and 20 per cent of the valuation, was only 30 per cent and 70 per cent respectively. Similarly, IPD/Drivers Jonas (1994) in a study of 7000 transactions over the period 1982-93 reported that the probability of the valuation being within plus or minus 10 and 20 per cent of the sale price was 42.1 per cent 65.8 per cent. Second, under SSAP 19 
investment properties have to be valued annually by persons holding a recognised professional qualification who have experience in the location and category of the properties concerned, as well as, at least every five years by an external valuer. Therefore, an internal valuer - one working for the company, even a director, can carry out the annual valuation, other than the five yearly one. Such valuers are likely to inflate or deflate the property values in the company's favour and this is often what appears to happen in practice (Barkham and Purdy, 1992). Even external valuers appear on occasion to be so influenced by the instructing company. Finally Barkham and Purdy (1992) state that property companies select accounting policies that appear to be inappropriate and which fail to reflect economic reality. This is further compounded by the fact that such companies often do not state which accounting policy is being adopted. Though legitimate, the resulting necessary adaptations are often used as an excuse to manipulate accounts, Barkham and Purdy (1992). Thus misleading investors and making it hard for them to fully assess the level of risk associated with an investment in the property company's shares.

In contrast, PTCs have lower levels of asset backing and their shares tend to stand at a premium to NAV. These companies are profit generators and their valuation is based on profits rather than assets. Whereas PICs have regular quality rental income with good growth prospects (including the benefits of reversions) and little need for retained profits, the sales revenues of PTCs are far more unpredictable and volatile. Therefore, PTCs shares are likely to be riskier than those of PICs (though this may be offset by higher expected returns). Consequently the share price of PTCs is derived in the same way as any other trading company by applying PER to the company's forecast earnings per share. The size of the PER depending on the market's expectation for that companies after-tax profits growth. Eventually property trading companies reach a stage in their growth where they tend to use their highly rated shares to acquire assets, thereby creating higher levels of asset backing. The market will then start to treat the company as PICs and value it with respect to its underlying NAV.

The different natures of property companies, their differing share valuations and the complexity of their accounts make the assessing of the true market value of a property company's shares difficult and uncertain. Nonetheless of the two types the estimation of the 'true' price of PTCs is likely to be more difficult than that of PICs. As a consequence PTCs are more likely to be underpriced than PICs.

In particular this paper sets out to test the following hypotheses:

Hypothesis one: the average initial return of PIC's IPOs is insignificantly positive.

Hypothesis two: the average initial return of PTC's IPOs is significantly positive and significantly greater than that of property investment company IPOs. 


\section{Data and Results}

The population under investigation covers all IPOs of UK commercial property company shares, as reported in Estate Gazette and S. G. Warburgs property reviews over the period from January 1986 to December 1995. Of the 57 companies identified from the above sources the issue prices and issue characteristic were obtained from a variety of source to verify which had been liquidated, which had been taken over and which had changed names. As a result the following seven companies were excluded as they were either not strictly coming to the market for the first time or were not commercial property companies:

a. Four reverse take-overs of quoted shell companies namely St. Mowden (reversed into Redmann Heenan International), Zurick (into Ecobric ), Prior ( into Knobs \& Knockers ) and TBI ( into Markheath).

b. Two relistings of suspended property companies, Merlin International in May 1987 and Bourne End in 1989, which itself was originally a reverse take-over.

c. One company whose property arm was secondary to its stated objective, in terms of revenue and stated purpose, of contracting and housebuilding, namely, the Try Group.

A further two companies were eliminated as they were both introductions ${ }^{1}$. The final sample made up of 48 property companies with offering dates spanning 1986-95.

The post issue share prices for the first trading day were obtained from Datastream. For those companies not covered by Datastream, the first day trade price was obtained from the new issue section of the Financial Times for pre-1992 issues and the Times post-1992. The first day's price is taken to be the middle market closing transaction price on the first day of public trading. 'Raw' data was used, unadjusted for subsequent bonus or rights issue or market factors. Due to the short interval involved raw returns calculated over a single day are considered justifiable.

For each initial public offering, two measures of initial performance were calculated:

(1) The first day unadjusted return for companies $i$, denoted by $\mathrm{R}_{\mathrm{i}}$, is defined as the continuously compounded return which when applied to the offer price (OP) at the beginning of the first trading day would accumulate to $\mathrm{P}$ by the close of the same day and is given by:

$$
\mathrm{R}_{\mathrm{i}}=\operatorname{Ln}\left(\mathrm{P}_{\mathrm{i}} / \mathrm{OP}_{\mathrm{i}}\right)
$$

(2) The first day adjusted return for issue $i,\left(\mathrm{AR}_{\mathrm{i}}\right)$, is defined as the first day unadjusted return less the equivalent change in the property sector price index $\left(R_{s}\right)$.

\footnotetext{
${ }^{1}$ If the company simply wishes to obtain a quotation for its existing shares rather than linking the admission to the market with the issue of new shares to the market as a whole, it can enter the market via an introduction. Provided the shares already in issue are of an amount and so widely held that their marketing when quoted can be assumed. Consequently introductions do not involve the raising of new capital for the company compared with offers for sale or placings.
} 


$$
\mathrm{AR}_{\mathrm{i}}=\mathrm{R}_{\mathrm{i}}-\mathrm{R}_{\mathrm{s}}
$$

The property sector price index obtained from Datastream.

Generally, these returns are calculated as the equal-weighted arithmetic average of initial return. However, various authors calculate market-adjusted returns using different benchmarks. For instance Ibbotson (1975) uses the return from the issue date to the calendar month-end rather than the first trading day as well as using riskadjusted returns. However the changes in the market-adjusted returns over so short an interval irrespective of the benchmark used does not materially effect the general conclusion.

\section{Results}

Of the total 48 companies, 26 (54 per cent) were PICs and 22 (46 per cent) were PTCs. However, whereas PIC IPOs are more evenly spread over the whole issue period, nearly all (95.6 per cent) of the PTCs IPOs occur in the 1986-9 issue period. This fact, needs to be accounted for when making comparisons between the two types of property company IPO initial returns (for the purposes of Hypothesis two) for the following reason. In other words PTCs came to the market when the property market and property sector in general were booming, which might exaggerate their average initial returns, thereby increasing the difference in average initial returns in comparison to PICs. However, it would seem reasonable to argue that the high initial returns earned by those PICs who came to the market in the boom would be offset by the lower initial returns on those that came in the recession of the early 1990s, leaving the average unaffected. That is account has to be taken of market timing. It is for this reason that the first day sector-adjusted returns are calculated.

\section{Initial returns}

Table 1 reports average first day unadjusted returns for the entire population (excluding the two issues that were introductions) and for PICs and PTCs separately. The total average first day return is 7.8 per cent. This is almost half that of the average initial return on all UK industrial IPOs of 14.3 per cent (Levis, 1993), but higher than the 1.91 per cent average initial return on UK investment trusts (Levis and Thomas, 1995) and the -2.82 per cent reported on REITs IPOs (Wang, Chan and Gau, 1992). These results accord with the Gerlich, Levis and Venmore-Rowland (1995) who using the percentage change in price over the first day as the initial return measure reported an all property company IPO average of 11.1 per cent.

The data also displays the characteristics of non-normality ${ }^{2}$, in line with the arguments of Rund (1993). Table 1, shows that all first day returns are significantly non-normal at greater than the $1 \%$ level of significance, due to both significant positive skewness and kurtosis in the data. In other words not only does the returns data exhibit positive skewness it is even more peaked, i.e. leptokurtic, than the normal distribution. Thus most of the returns are even more tightly clustered around the mean than compared with the normal distribution. This is true even if adjusted returns are used. Whether

\footnotetext{
${ }^{2}$ In order to test for normality we employ the Jarque-Bera test which is asymptotically distributed as Chi-squared with two degrees of freedom, (see Jarque and Bera, 1980 and Bera and Jarque, 1982). The test having proved to be efficient in Monte Carlo experiments for relatively small samples (Bera and Jarque, 1981 and Jarque and Bera, 1987).
} 
this positive skwness is as a consequence of price support by the underwriters is not known.

Table 1: Unadjusted and Adjusted First Day Returns

\begin{tabular}{|c|c|c|c|c|c|c|}
\hline & \multicolumn{2}{|c|}{$\begin{array}{c}\text { All Companies } \\
\text { First Day Returns }\end{array}$} & \multicolumn{2}{|c|}{$\begin{array}{c}\text { Property Investment } \\
\text { Companies }\end{array}$} & \multicolumn{2}{|c|}{$\begin{array}{l}\text { Property Trading } \\
\text { Companies }\end{array}$} \\
\hline & Unadjusted & Adjusted & Unadjusted & Adjusted & Unadjusted & Adjusted \\
\hline Mean & 7.79 & 8.33 & 4.11 & 5.32 & 12.14 & 11.90 \\
\hline Std. Deviation & 16.63 & 17.73 & 17.55 & 19.87 & 14.68 & 14.46 \\
\hline T-statistic ${ }^{1}$ & 3.25 & 3.26 & 1.19 & 1.3656 & 3.88 & 3.86 \\
\hline Probability & 0.0022 & 0.0021 & 0.2435 & 0.1842 & 0.0009 & 0.0009 \\
\hline Percent negative & 20.83 & 20.83 & 30.77 & 26.92 & 9.91 & 13.64 \\
\hline Skewness & 1.39 & 2.06 & 1.61 & 2.48 & 1.71 & 1.58 \\
\hline Kurtosis & 7.32 & 10.24 & 8.90 & 12.12 & 5.91 & 5.33 \\
\hline Jarque-Bera test & 52.81 & 138.82 & 48.88 & 116.85 & 18.43 & 14.11 \\
\hline Probability & 0.000 & 0.000 & 0.000 & 0.000 & 0.000 & 0.001 \\
\hline \multicolumn{7}{|c|}{ Difference in Means/Median PICs and PTCs } \\
\hline \multirow{2}{*}{\multicolumn{3}{|c|}{ ANOVA }} & Unadjusted & \multicolumn{3}{|c|}{ Adjusted } \\
\hline & & & 2.89 & 1.66181 & & \\
\hline & \multicolumn{2}{|c|}{ Probability } & 0.09571 & 0.20381 & & \\
\hline & \multicolumn{2}{|c|}{ Mann-Whitney U-test } & 1.86 & 1.69 & & \\
\hline & \multicolumn{2}{|c|}{ Probability } & 0.06257 & 0.09173 & & \\
\hline
\end{tabular}

Note: 1 Test whether the initial returns are significantly different from zero

In addition the unadjusted and adjusted average the first day return, for the whole sample of property companies, is positive and significantly different from zero ${ }^{3}$. Implying that on the first day the property company issues show signs of underpricing. However, there are differences in terms of significance between PICs and PTCs, as suggested above. The average first day return for PICs although positive is not significantly different from zero. It is the highly significantly positive average return of PTCs that leads to the general conclusion that overall property company first day returns are significantly positive. In addition only 9.9 per cent of PTCs (two issues) started trading below their offer price as opposed to the 30.8 per cent of the total number of PICs.

Finally initial average (mean and median) returns are significantly higher for PTCs (12.14 and 9.22 per cent) than for PICs (4.11, 4.61 per cent), based on parametric ANOVA and non parametric Mann-Whitney U-tests. This result holds even after adjusting for property sector timing.

\footnotetext{
${ }^{3}$ The use of the standard t-test in the presence of non-normality may be suspect but the very high significance levels of the overall data and that for PTCs which are both significant at greater the $1 \%$ percent level, suggests the results are likely to be robust to any departures from normality.
} 


\section{Conclusions}

This paper presents empirical evidence for $48 \mathrm{UK}$ commercial property company IPOs broken down into PICs and PTCs IPOs. From which a number of conclusions can be drawn. First, PICs show a positive but insignificant average initial return of 4.11 per cent. This is below the average initial return on all UK industrial IPOs of 14.3 per cent but higher than the 1.91 per cent average initial return on UK investment trusts and the -2.82 per cent reported on REITs IPOs. Second, the average initial returns on PTCs were 12.14 per cent, similar to the all UK industrial IPOs but more importantly significantly higher than for PICs IPOs. The result holds true even after adjusting for market timing and sector returns.

All of which suggests that the first day return performance of PICs more like that of investment companies and REITS, showing low but insignificant positive returns. In contrast PTCs first day returns appear more in line with previous studies of industrial companies, displaying significant underpricing. In other words PICs are valued on their underlying asset value, a valuation that is likely to be more precise than the valuation of PTCs that are priced on projected earnings and PER. The results of Gerlich, Levis and Venmore-Rowland (1995) which covers almost the same data and period of analysis as here need to be modified in light of the differences between the valuation of the two types of property company. 


\section{References}

Allen, F and Faulhaber, G. R. (1989) "Signalling by underpricing in the IPO market", Journal of Financial Economics, Vol. 23, No. 2, pp 303-323.

Barkham, R. J. (1997) "The financial structure and ethos of property companies: An empirical analysis", Construction Management and Economics, Vol. 15, pp 441-456.

Barkham, R. J. and Purdy, D. E. (1992) "Property company financial reporting: Potential weaknesses", Journal of Property Valuation and Investment, Vol. 11, No. 2, pp 133-144.

Baron, D. P. (1982) "A model of the demand for investment bank advising and distribution services for new issues", Journal of Finance, Vol. 37, pp 955-76.

Beatty, R. P. and Ritter, J. R. (1986) "Investment banking, reputation, and the underpricing of initial public offerings." Journal of Financial Economics, Vol. 15, pp. 213-32.

Below, S., Zaman, M. A. and Mcintosh, W. (1995) "The pricing of real estate investment trust initial public offerings", Journal of Real Estate Finance and Economics, Vol. 11, pp 55-64.

Benveniste, L. M. and Spindt, P. A. (1989) "How investment bankers determine the offer price and allocation of new issues", Journal of financial Economics, Vol. 24, No. 2, pp 343-361.

Bera, A.K. and Jarque, C.M. (1981) "Efficient tests for normality, homoscedasticity and serial independence of regression residuals: Monte Carlo evidence", Economic Letters, Vol. 7, pp 313-318.

Bera, A.K. and Jarque, C.M. (1982) "Model specification tests", Journal of Econometrics, Vol. 20, pp 59-82.

Canon, S.E. and Vogt, S. (1995) 'REITs and their management: An analysis of organisational structure, performance and management compensation', Journal of Real Estate Research, Vol. 10, No. 3, pp 297-317.

Investment Property Databank/Drivers Jonas (1994) The Variations in Valuations Fourth Report December 1994, London: Drivers Jonas.

Gerbich, M., Levis, M. and Venmore-Rowland, P. (1995) "Property initial public offerings: regulations, costs and price reactions", Journal of Property Finance, Vol. 6, No. 1, pp 38-54.

Grinblatt, M. and Hwang, C. Y. (1989) "Signalling and the pricing of new issues", Journal of Finance, Vol. 44, No. 2, June, pp 393-420. 
Hughes, P. J. and Thakor, A. V. (1992) "Litigation risk, intermediation, and the underpricing of initial public offerings", Review of Financial Studies, Vol. 5, No. 4, pp 709-42.

Ibbotson, R. G. (1975) "Price performance of common stock new issues", Journal of Financial Economics, Vol. 12, pp 235-72.

Ibbotson, R. G. and Ritter, J. R. (1995) "Initial public offerings" In: Jarrow R.A., Maksimovic V. and Ziemba, W.T. (eds.) Handbooks in Operations Research and Management Science, Volume 9: Finance, $1^{\text {st }}$ ed., North Holland: Elsiver Science pp 993-1016.

Ibbotson, R. G., Sindelar, J. L. and Ritter, J. R. (1988) "Initial public offerings", Journal of Applied Corporate Finance, Vol. 1, Summer, pp 37-45.

Jarque, C.M. and Bera, A.K. (1980) "Efficient tests for normality, homoscedasiticty and serial independence of regression residuals", Economic Letters, Vol. 6, pp 255259.

Jarque, C.M. and Bera, A.K. (1987) "A test for normality of observations and regression residuals”, International Statistical Review, Vol. 55, No. 2, 163-172.

Levis, M. (1990) "The winner's curse problem, interest costs and the underpricing of initial public offerings", Economic Journal, Vol. 100, March, pp 76-89.

Levis, M. (1993) "The long run performance of initial public offerings: The UK experience 1980-88", Financial Management, Vol. 22, No. 1, pp 28-41.

Levis, M. and Thomas, D. C. (1995) "New investment trusts offerings: behaviour and price performance", Professional Investor, March, pp 28-30.

Loughran, T., Ritter, J.R. and Rydqvist, K. (1994) "Initial public offerings: international insights", Pacific-Basin Finance Journal, Vol. 2, pp165-99.

Matysiak, G. and Wang, P. (1995) "Commercial property market prices and valuation: analysing the correspondence", Journal of Property Research, Vol. 12, No. 3, pp 181202.

Michaely, R. and Shaw, W. H. (1994) "The pricing of initial public offering: tests of adverse selection and signalling theories", Review of Financial Studies, Vol.7, No. 2, Summer, pp 279-319.

Muscarella, C. J. and Vetsuypens, M. R. (1989) “A simple test of Baron's model of IPO underpricing”, Journal Financial Economics, Vol. 24, pp 125-35.

Ritter, J. R.. (1987) "The costs of going public", Journal of Financial Economics, Vol. 19, pp 269-282. 
Rock, K. (1986) "Why new issues are underpriced", Journal of Financial Economics, Vol. 15, pp 187-212.

Ruud, J. R. (1993) "Underwriter price support and the IPO underpricing puzzle", Journal of Financial Economics, Vol. 34, pp 135-151.

Tinic, S. M. (1988) "Anatomy of initial public offerings of common stock", Journal of Finance, Vol. 43, No 4, pp 789-823.

Wang, K., Chan, S H. and Gau, G. W. (1992) "Initial public offerings of equity securities: Anomalous evidence using REITs", Journal of Financial Economics, Vol. 31, pp 381-410.

Weiss, K. (1989) "The post-offering price performance of closed-end funds", Financial Management, Vol. 18, No 3, pp 57-67.

Welch, I. (1989) "Seasoned offerings, imitation costs, and the underpricing of initial public offerings", Journal of Finance, Vol. 44, No. 2, June, pp 421-449.

Welch, I. (1992) "Sequential sales, learning and cascades", Journal of Finance, Vol. 47, No. 2, pp 695-732. 